\title{
The Effect of Different Kinds of Animal Housing on Parameters of Collagen Metabolism in Guinea Pigs
}

\author{
By R. Wepler, H. Burkhardt, Frauke Burkhardt and K. Rommel
} Military Hospital Ulm (Hospital Commander: Colonel MC B. Stolze) and Department of Clinical Chemistry,
University of Ulm

(Received March 3/June 30, 1977)

Summary: Parameters of collagen metabolism were investigated in guinea pigs, both untreated and treated with glucocorticoids. One series consisted of animals housed under normal conditions, the others of SPF animals from the same strain. There are marked differences in certain parameters, including the hydroxyproline content and the reaction of the collagen to glucocorticoids.

\section{Die Wirkung verschiedener Haltungsbedingungen auf Parameter des Kollagenstoffwechsels bei Meerschweinchen}

Zusammenfassung: Die Untersuchung von Parametern des Kollagenstoffwechsels bei unbehandelten und mit Glukokortikoiden behandelten Meerschweinchen wurde an Tieren unter normalen Haltungsbedingungen und an solchen unter SPF-Bedingungen durchgeführt. Dabei ergaben sich zum Teil erhebliche Unterschiede sowohl im Hydroxyprolingehalt als auch in der Reaktion des Kollagens auf Glukokortikoide.

\section{Introduction}

When studying the influence of corticosteroids on the metabolism of collagen in guinea pigs, we found the kind of animal housing to have a marked effect on the weight gain of the animals and on the hydroxyproline content in different tissues.

In the literature, conflicting results about the influence of glucocorticoids on the collagen metabolism have been reported $(1,2,3)$. Our results indicate that the reported effects may at least in part be due to the way in which the animals are housed.

\section{Material and Methods}

The investigations were performed with specified pathogen free (SPF) male guinea pigs, all animals being exactly 15 days old at the beginning of the experiments. The animals were housed in one series in a common animal room in the hospital laboratory area, and in a second series in the animal house of Thomae, Biberach, under a controlled microbiological environment. Both series were fed "Śnif-G-guinea pig food" and were sacrificed under anesthesia on day 15 after the beginning of the experiment. They were treated with fluocortolone $(3.0 \mathrm{mg} / \mathrm{kg} \cdot \mathrm{d})$, made into solution with a mixture of benzylbenzoate and ricinus oil (volumes, $4 \mathrm{ml}+6 \mathrm{ml}$ ). The sterilized solution was injected daily between 7.30 and 8.30 a.m. into the abdominal skin. The injectèd volume ranged between 1 and $2 \mathrm{ml}$ per $\mathrm{kg}$, each animal was weighed before the injection. The preparation of skin and bones was performed in the same way and by the same person in both series. Our parameters were the total hydroxyproline content of skin and bones and that of neutral salt-soluble and citrate-soluble fractions.

In the case of the bones, both ossa parietalia were removed and the surrounding cartilage was cut off. The bones were put into cold acetone for 4 hours (delipidation) and after that they were cut into small pieces with a pair of scissors and then pulverized with an electrical mortar, $5 \times 30$ seconds (Dismembrator, Braun, Melsungen). A weighed amount of the pulverized bone (about 5-10 mg) was mixed with a buffer containing $0.15 \mathrm{~mol} / \mathrm{l} \mathrm{NaCl}$ and $0.45 \mathrm{~mol} / \mathrm{l}$ citrate, and extracted for 24 hours in the cold $\left(4^{\circ} \mathrm{C}\right)$.

In the case of the skin a small piece of back skin (about $2 \times 2 \mathrm{~cm}$ ) was frozen in liquid nitrogen and pulverized in the Dismembrator. The mortar was recooled in liquid nitrogen after each run. The powder was delipidated in cold acetone for 4 hours. After drying, extraction of the collagen fractions was performed in the same way as above.

The concentration of hydroxyproline in the $0.45 \mathrm{~mol} / 1$ fractions not only reflects the collagen soluble in $0.45 \mathrm{~mol} / 1$ $\mathrm{NaCl}$ but also that soluble in $0.15 \mathrm{~mol} / 1 \mathrm{NaCl}$. In the same way the citrate fraction contains the citrate-soluble, the $0.45 \mathrm{~mol} / \mathrm{l}$ and the $0.15 \mathrm{~mol} / \mathrm{l}$-soluble fractions, so that the sum of these fractions is as high or higher than the total hydroxyproline content.

All samples were centrifuged and $1 \mathrm{ml}$ of the clear supernatant was hydrolyzed with $1 \mathrm{ml}$ of $\mathrm{HCl}(10 \mathrm{~mol} / \mathrm{l})$ for 12 hours at $115^{\circ} \mathrm{C}$.

For the determination of the total hydroxyproline content of the bone and the skin, a weighed amount (about $5 \mathrm{mg}$ ) of the powder was hydrolyzed with $\mathrm{HCl}$. Hydroxyproline was determined with a Technicon AutoAnalyzer according to Grant (4). 


\section{Results}

\section{Development of the animals}

The animals without steroid therapy had under normal environment a mean weight gain of $14.7 \%$ as related to the initial weight (tab. 1), and the SPF animals of $39.1 \%$. Under steroid therapy the "normal" animals had a weight gain of only $3.8 \%$ while SPF animals gained $39.3 \%$.

\section{Total hydroxyproline content of skin and bones}

Among the untreated animals, SPF animals had a lower total hydroxyproline content of the skin $(535 \mathrm{mmol} / \mathrm{kg}$ tissue) as compared to the others (671 mmol $/ \mathrm{kg}$ tissue). In the treated animals, SPF and non-SPF show no difference in the hydroxyproline content of the skin and the bones.

\section{Collagen fractions}

The hydroxyproline content of the bone fractions of untreated animals was higher in normally housed animals than in SPF. The mean standard deviation (s) of the measured values in the fractions was $14.1 \mathrm{mmol} / \mathrm{kg}$

Tab. 1. Measured values in normal housed and SPF animals.

\begin{tabular}{|c|c|c|c|c|}
\hline & & $\begin{array}{l}\text { normal } \\
\text { housing }\end{array}$ & & $\begin{array}{l}\text { SPF } \\
\text { housing }\end{array}$ \\
\hline $\begin{array}{l}\text { weight gain } \\
\text { (\% of initial } \\
\text { weight) }\end{array}$ & $\begin{array}{l}\text { untreated } \\
\text { treated }\end{array}$ & $\begin{array}{r}14.7 \\
3.8\end{array}$ & $\begin{array}{l}x x x \\
x x x\end{array}$ & $\begin{array}{l}39.1 \\
39.3\end{array}$ \\
\hline $\begin{array}{l}\text { Total hydroxy- } \\
\text { proline of skin } \\
\text { (mmol/kg } \\
\text { tissue) }\end{array}$ & $\begin{array}{l}\text { untreated } \\
\text { treated }\end{array}$ & $\begin{array}{l}671( \pm 152) \\
738( \pm 44.2)\end{array}$ & $x \times x$ & $\begin{array}{l}535( \pm 54.2) \\
750( \pm 55.7)\end{array}$ \\
\hline $\begin{array}{l}\text { Total hydroxy- } \\
\text { proline of } \\
\text { bones (mmol/ } \\
\text { kg tissue) }\end{array}$ & $\begin{array}{l}\text { untreated } \\
\text { treated }\end{array}$ & $\begin{array}{l}213( \pm 28.2) \\
226( \pm 16.0)\end{array}$ & & $\begin{array}{l}216( \pm 20.6) \\
211( \pm 11.4)\end{array}$ \\
\hline \multicolumn{5}{|c|}{$\begin{array}{l}\text { Hydroxyproline } \\
\text { content of } \\
\text { skin fractions }\end{array}$} \\
\hline $\begin{array}{l}0.45 \mathrm{~mol} / \mathrm{l} \\
\text { citrate solution }\end{array}$ & $\begin{array}{l}\text { untreated } \\
\text { treated } \\
\text { untreated } \\
\text { treated } \\
\text { untreated } \\
\text { treated }\end{array}$ & $\begin{array}{l}9.92( \pm 3.81) \\
11.4( \pm 4.57) \\
45.8( \pm 17.5) \\
45.0( \pm 9.92) \\
159( \pm 48.0) \\
69.9( \pm 8.39)\end{array}$ & $\begin{array}{l}x x x \\
x x x \\
x x x \\
x x x\end{array}$ & $\begin{array}{l}13.7( \pm 3.81) \\
19.0( \pm 3.05) \\
55.7( \pm 9.92) \\
51.1( \pm 18.3) \\
34.3( \pm 6.10) \\
48.0( \pm 12.2)\end{array}$ \\
\hline \multicolumn{5}{|l|}{$\begin{array}{l}\text { Hydroxyproline } \\
\text { content of } \\
\text { bone fractions }\end{array}$} \\
\hline $\begin{array}{l}0.15 \mathrm{~mol} / 1 \\
0.45 \mathrm{~mol} / 1 \\
\text { citrate solution }\end{array}$ & $\begin{array}{l}\text { untreated } \\
\text { treated } \\
\text { untreated } \\
\text { treated } \\
\text { untreated } \\
\text { treated }\end{array}$ & $\begin{array}{l}76.3( \pm 13.7) \\
70.2( \pm 22.1) \\
95.4( \pm 12.9) \\
78.6( \pm 17.5) \\
119( \pm 15.2) \\
87.7( \pm 16.8)\end{array}$ & $\begin{array}{l}x x x \\
x x x \\
x x x \\
x x x \\
x x x\end{array}$ & $\begin{array}{l}36.6( \pm 6.11) \\
36.6( \pm 8.39) \\
42.7( \pm 6.87) \\
76.3( \pm 16.0) \\
53.4( \pm 9.92) \\
35.8( \pm 6.87)\end{array}$ \\
\hline
\end{tabular}

$X X X$ Indicates that the differences are statistically significant $(\mathrm{p}<0.05)$ tissue in the normal housed animals and only $7.6 \mathrm{mmol} /$ $\mathrm{kg}$ tissue in SPF animals.

After treatment the values show a similiar pattern except for the $0.45 \mathrm{~mol} / 1$ fraction. The mean standard deviation in normally housed animals is nearly twice that of SPF animals.

The hydroxyproline content of the skin fractions shows, in the treated and the untreated group, the same differences between normally housed and SPF animals: SPF animals had a higher hydroxyproline content in the $0.15 \mathrm{~mol} / 1$ fraction and in the $0.45 \mathrm{~mol} / \mathrm{l}$ fraction and a lower content in the citrate-soluble fraction.

\section{Changes in the hydroxyproline content after glucocorticoid therapy}

In the bone the total hydroxyproline content and that of the $0.15 \mathrm{~mol} / \mathrm{l}$ fraction in both groups of animals showed no change after treatment. In the $0.45 \mathrm{~mol} / 1$ fraction normally housed animals showed a decrease, while SPF animals showed an increase of the hydroxyproline content after the treatment.

In the skin of normally housed animals, the treatment caused no change in the total hydroxyproline content or the content of the $0.15 \mathrm{~mol} / 1 \mathrm{l}$ fraction, while SPF animals showed an increase. In the citrate-soluble fraction, normally housed animals showed a decrease, while SPF animals showed an increase in the hydroxyproline content after treatment.

\section{Discussion}

We will not discuss the implication of these results for the metabolism of collagen. We are more concerned with the variation in results due to environmental changes. Both animal groups came from the same strain. We started our investigations with normally housed animals, but because of a large variation in the results we repeated the experiment, leaving the animals in their known SPF environment during the period of treatment.

An important parameter in these investigations is the development of the animals: after changing their environment, the animals gained less weight in spite of being fed the same food. We assume that this change of environment and the adaptation to a "normal" bacterial flora has such a marked influence, that the further development of the animals is slowed down. This effect, which can be seen clearly in untreated animals, was much more pronounced under a corticoid treatment, where normally housed animals only had a very small weight gain and 20 to $30 \%$ of the animals actually died. SPF animals showed no difference from their untreated controls.

As we have shown, there are differences in some parameters of collägen metabolism under different micro- 
biological environments. The reaction of these parameters to glucocorticoid therapy is, at least in part, opposite in normal housed and in SPF animals. One cannot exclude that similiar results may be obtained

\section{References}

1. Vogel, H. G. (1974), Connect. Tissue Res. 2, 177-182.

2. Manthorpe, R., Helin, G., Kofod, B. \& Lorenzen, J. (1974), Acta Endocrinol. 77, 310-324. in studies of metabolic systems other than that of collagen. This clearly shows the problems of comparing results from the literature, especially when exact data about the experimental conditions are lacking.

3. Houck, J. C. \& Patel, Y. M. (1965), Nature (Lond.) 206, 158-160

4. Grant, R. A. (1964), Intern. Technicon Symposion, Frankfrut.

Dr. R. Wepler Bundeswehrkrankenhaus Mähringer Weg 105/I 7900 Ulm 
